\title{
KIR Ligand Negative
}

National Cancer Institute

\section{Source}

National Cancer Institute. KIR Ligand Negative. NCI Thesaurus. Code C150650.

An indication that expression of ligands for the killer-cell immunog lobulin-like receptors

have not been detected in a sample. 